\title{
Our 25+ Year Journey To AACSB Accreditation
}

Robert Bing, (Email: bingr@wpunj.edu), William Paterson University Elizabeth C. Ekmekjian, (Email: ekmekjiane@wpunj.edu), William Paterson University Berch Haroian, (Email: haroianb@wpunj.edu), William Paterson University Martin Rudnick, (Email: rudnickm@wpunj.edu), William Paterson University

\begin{abstract}
How does a publicly supported university with a primary focus on teaching, achieve accreditation from the premier agency and service organization for business schools all over the world, the Association to Advance Collegiate Schools of Business (AACSB)? Our journey began in 1978 when a college department hired a Dean, became a separate business school and had a vision to become a successful leader in business education. Our goal was achieved and culminated on January 7 , 2005 with the accreditation of our undergraduate and graduate business programs. The who, what, where, when and why of our 25+ year journey will be provided. Particular emphasis will be placed on our numerous hurdles and how the goal was achieved such as funding availability; curriculum reform; raising publication rates, and why it took so long to get accredited.
\end{abstract}

\section{PREFACE}

n response to a rapidly growing population of high school graduates under the age of 21, the State of New Jersey in 1967 mandated that each of its eight publicly supported teacher education colleges develop into multi-purpose educational institutions. One of those institutions of higher education, William Paterson
College (WPC), began to offer diverse courses including courses and majors in business and accounting. By 1977 some eleven full-time faculty members of various business disciplines (four accountants, three economists, two marketing/management, and two lawyers) were housed in a business department. The Dean of Administrative Studies was responsible for the business department, K-12 education programs, the departments of criminal justice and computer science.

In 1977 WPC chose to establish a separate business school with its own Dean, and was designated the SOM (SOM). Two disparate programs, criminal justice and computer science were now reassigned to the SOM. In August 1978, the first Dean was hired with mandates to secure AACSB accreditation for the undergraduate business programs and establish and obtain accreditation of an MBA program.

\section{THE EARLY YEARS: 1978 - 1991}

The new Dean soon discovered that he would face numerous hurdles that would make accreditation status extremely difficult. AACSB requirements created several immediate priorities: (1) implement an AACSB approved course of study; (2) adhere to AACSB faculty/student ratios; (3) secure terminally qualified faculty; and (4) raise publication rates of business faculty. The Dean and faculty attended various conferences sponsored by the AACSB to understand these requirements/standards. In addition, in the early 1980's, a consultant was hired to advise the SOM on the proper steps to achieve accreditation.

The faculty was more than willing to implement an AACSB curriculum and worked diligently to do so. After agreement was reached by the business faculty, WPC approval was required. All new degree and course changes had to be approved by the WPC Faculty Senate. Some members of this body perceived that the proposed course requirements of some sixty credits would impact on their own departments and faculty. Questions were raised as to the validity of a number of courses and the importance thereof. However, in the end, the business curriculum (both 
undergraduate and graduate) was approved by the Faculty Senate. The graduate curriculum required additional approval by: the President of WPC, the Board of Trustees of WPC, and statewide bureaucracy. Fortunately, no problems were encountered and hurdle number one was resolved.

Hurdle number two, student/faculty ratios, presented a large problem as well. Student enrollment was approximately 4,000 with an initial full-time staff numbering eleven. AACSB standards would require hiring an enormous number of full-time, terminally qualified faculty. For example, these standards would require a full-time faculty of 35-40, with a student enrollment of some 1,200. This created a need to both reduce the student load and increase full-time faculty course coverage. Both sides of this equation were problematic.

First, there was a wrinkle concerning student enrollment caused by State funding on a capitation basis. Thus any reduction in students enrolled in the SOM, whose majors contained a majority of the enrollment of WPC, would seriously impact WPC's funding. Accordingly, any attempt to reduce student enrollees either by testing, i.e. higher SAT scores, or maintaining at least a minimum grade point average (GPA), ran headlong into organizational problems. Several ideas were implemented which in combination reduced the student load without impacting on college-wide enrollments. Current policy for business and accounting majors required a 2.0 GPA for entry into and graduation from the SOM. The faculty of the SOM, with the concurrence by the Faculty Senate and WPC administration, implemented a more rigorous two-stage portal, increasing GPA requirements. Students were required to take four core courses at WPC: Macroeconomics, Microeconomics, Financial Accounting and Managerial Accounting and maintain a 2.5 GPA for those courses. The second portal was a requirement of an overall 2.5 GPA in all courses taken at WPC. The portal requirements were coupled with active advisement by the entire faculty of WPC and its advisement office to advise students not meeting the criteria to change into majors that were looking for additional student enrollment and that accepted a lower GPA. Over the next several years majors such as Communications and Sociology were the beneficiaries of a re-allocation of student enrollment, which helped the SOM reduce the student load from the initial 4,000 to approximately 2,500.

The Faculty issue of hiring full-time, terminally qualified faculty was even thornier. There was a strong union presence in the form of the AFT (the American Federation of Teachers), at each of the eight aforementioned State institutions. The AFT negotiated with the State of New Jersey, a State known for it's under funding of public higher education. A major conflict arose between state/union negotiated salaries and what the current market commanded for business and accounting faculty. The problem was specifically caused by the pay scales under the union contract. As is often the case under union contracts, there existed a rigid salary scale and steps within the scale. All faculty of given rank, credentials and years of service were to be paid an identical salary. Therefore, a Finance Professor, with multiple academic and market options was to be paid the same salary as an English Professor. This coupled with the chronic under funding of the college by the State effectively crippled faculty recruiting for the SOM. The only alternative, in order to match competitive salaries, was to trade rank (Associate or Full Professor) for the approximate competitive income. Although employed for a time, this stratagem required the transferring of senior faculty lines to the SOM at the expense of faculty in the other WPC schools. This reallocation of resources was a major sore spot for years. Upon discovery of this stratagem by other non-business faculty/administration, its use was discontinued. After eight years, while the SOM was able to increase its full-time faculty to 31, the challenge of hiring and retaining terminally qualified faculty remained.

With respect to the issue of raising publication rates, the problem was that WPC was primarily a teaching institution. Retention, tenure and promotion were based on teaching, service and scholarly activity, however, there was no defined criteria as to the level or amount of each requirement. Accordingly, it was possible to be tenured without any publications. Travel money was scarce and the teaching load was twelve credits. A combination of these factors provided little motivation and made it very difficult to get faculty to engage in serious scholarly activity. The faculty might say that their goal was AACSB accreditation however the commitment for research did not exist. Because of this, there was a very low level of publications from the existing faculty. What was needed was to change the emphasis of the SOM and thus change the mind set of the faculty. Unfortunately this did not happen during the early years. 
By 1986, eight years after its founding, the SOM was still not able to seek accreditation. It had too many students (2,500); too few faculty (31); budget concerns; hiring issues (not able to meet competitive market salaries under the contractually negotiated pay scales); and insufficient faculty scholarship.

The inability to even apply for AACSB accreditation led a new WPC administration to seek new SOM leadership. Over the next five years, 1986-1991, no less than four Deans were hired and either quit or were replaced. WPC and the SOM, for the time being, abandoned the goal of seeking accreditation.

\section{THE DARKEST YEARS: 1991-1996}

In 1991 a new Vice President of Academic Affairs undertook a restructuring of the academic schools within WPC. Seven schools were consolidated into four; one such combination of the SOM, Humanities and Social Sciences resulted in the new School of Humanities, Management and Social Science (HMSS). This effort would streamline administration, combine resources and eliminate the salaries of several Deans, however, the SOM lost its identity.

A new Dean of the HMSS was appointed shortly thereafter. Her discipline was in the area of the Humanities and she admittedly had no background or knowledge of business and the AACSB accreditation procession. This appointment emphasized the formal abandonment of the business accreditation goals by the WPC administration.

Subsequently, the Vice President of Academic Affairs undertook a comprehensive program review of WPC and its course offerings. As a result, the major in Economics was discontinued. The evisceration of the business program was now complete. The lack of a visible business program was continuously cited by parents and local groups. WPC is housed in Wayne, New Jersey, the State which is home to corporate headquarters of over 50 fortune 500 firms. The lack of a business school presence was an anomaly. In 1996, a further administrative review was to deal with this issue.

\section{THE SUN SHINES: 1996-2000}

1996 saw the hiring of a new Vice President of Academic Affairs. The new chief academic officer was appointed Provost and Executive Vice President, a newly created position. As such, he yielded substantial power and authority. One of his first actions was to meet with the business faculty. In response to them and to the external community, he established an autonomous School of Business.

In the spring of 1997, WPC applied for and received University status, thus it was now known as William Paterson University (WPU). The School of Business was now renamed the College of Business (COB). Simultaneously, the Board of Trustees charged the COB with the mandate of AACSB accreditation.

A Dean for the resurrected School of Business was appointed from within the faculty of business. He was a long time faculty member and experienced department chairperson. The Dean and his senior faculty sought and received a pledge from the administration that the appropriate level of financial resources would be provided for the new accreditation effort. In 1998, based on the Board's mandate and the administration's commitment, the COB made initial application for accreditation by the AACSB.

In support of its commitment to the $\mathrm{COB}$, the administration's new University Master Plan provided for a new building dedicated to business and then fate intervened. In close proximity to the main campus a beautiful, former corporate headquarters on 53 acres became available for purchase. Through a combination of purchase and donation by the Seller the University was able to obtain title to this extraordinary property. The new facility would provide state-of-the-art classrooms and an enhanced technologically advanced environment for WPU students, faculty and staff.

Unfortunately, however, additional accreditation funding became a major issue. While hiring of full-time faculty was permitted, it was limited and funding efforts for scholarship and new programs were in short supply. These issues became problematic during the Dean's tenure and became factors in his resignation in fall 2000. 


\section{THE ACCREDITATION PROCESS: 2001-2005}

Commencing in early 2001, several events occurred which began a steady march to accreditation. Funding opportunities couldn't have been timed better. During the spring 2001 semester, the founder and former CEO of ETrade Financial, Christos M. Cotsakos, an alumnus of WPU, endowed the COB with a \$10 million dollar gift in support of the rehabilitation of the $\mathrm{COB}$ and its accreditation efforts. The College was renamed the Christos M. Cotsakos College of Business (CCOB). In addition, discussions were being held with $\mathrm{E}^{*}$ Trade Financial for the creation of the $\mathrm{E}^{*}$ Trade Financial Learning Center (a simulated trading room which opened in Fall 2002 funded partially through a grant by E*Trade Financial).

In July 2001, an outstanding Dean candidate was appointed who was hired specifically to obtain accreditation. The new Dean had recently assisted with securing AACSB accreditation at another University in New Jersey. His familiarity with AACSB expectations, procedures and requirements proved to be invaluable. He was also able to secure the support of the senior faculty and embarked on a recruiting drive. True to their word the administration provided special lines to hire some 20 full-time, terminally qualified faculty members-all on tenure track positions. The curriculum was revamped once again in accordance with new AACSB requirements and won handy approval from the faculty senate with the backing of the Executive Vice President and the President.

Another substantial grant was provided by Russ Berrie, the former CEO of Russ Berrie and Company. Five million dollars was provided to establish a professional sales program within the CCOB. January 2003 marked the opening of the Russ Berrie Institute for Professional Sales. In Fall 2003, the Russ Berrie Professional Sales Laboratory was opened, supported by additional grand funding from Russ Berrie and Company. The Laboratory has a number of interview rooms where students can perform mock presentations/interviews. These meetings are taped and the students learn from their performances.

Several additional novel innovations were also introduced.

- $\quad$ To encourage faculty to publish, a sliding scale of rewards including fully paid presentation trips, and direct monetary awards for publications through summer research funding was put into place. This was made possible by the various corporate grants provided to the $\mathrm{CCOB}$ and caused a renaissance of scholarly work.

- A program of Professional Enrichment was implemented requiring all students to attend eight 60-75 minute activities to improve their business skill sets. These in conjunction with the senior capstone course enabled the new program to meet and exceed almost all AACSB requirements.

- $\quad$ Writing and public speaking were required in many business courses for all students.

- Interested groups such as Alumni, Businessmen, Students were formed into a Stakeholders Group which provided feedback on the success (or failure) of students and curriculum.

- $\quad$ Faculty were trained and paid to advise students. No student was permitted to register for courses without seeing an advisor. This system was enforced with the use of a PIN that the student needed to register and could only be obtained by seeing their designated advisor.

Our earlier problem of State funding via a capitation basis had long since been modified as the State now funds on a grant basis. While this continues to present certain funding issues, it removed the "quality" for "quantity" concern. The CCOB implemented and maintained strict adherence to a policy which required higher student GPAs. Students with more than three grades below a $\mathrm{C}$ - are not allowed to remain in or graduate from the CCOB.

These and other measures allowed the CCOB to petition for a site visit by the AACSB. This visit, some 26 years in the making took place in October 2004. A team of three experienced Deans, all from AACSB Schools examined every aspect of $\mathrm{CCOB}$ programs. Their decision and recommendation was to grant Accreditation status to the CCOB; without any restrictions or reservations. The 26 year odyssey of the WPU CCOB was over. 


\section{SUMMARY: WHY DID WE SUCCEED?}

The student enrollment is currently 1,500 and growing. The full-time faculty exceeds 40 well-qualified women and men. The Dean provided imaginative and innovative leadership for the issues facing the CCOB. The commitment and support of the Provost, President and Board of Trustees of the University was critical for the success of the process. The senior faculty internally became a strong support group and helped bridge the gap between the $\mathrm{CCOB}$ and the rest of the campus. In conclusion, each of the above factors, combined with the procurement of a new state-of-the-art facility, obtaining significant grants, expanded full-time faculty, and exploding publications all contributed to the $\mathrm{CCOB}$ applying for and receiving accreditation. We are proud to be members of a faculty that has been tried, tested, and victorious!

\section{NOTES}




\section{NOTES}

